\title{
Proper Energy Mix: A Solution to Stable Power Supply in Nigeria
}

\author{
${ }^{1}$ John Tarilanyo Afa \\ ${ }^{2}$ V.I.E. Anireh \\ ${ }^{1}$ Department of Electrical/Electronic Engineering, Niger Delta University \\ P.M.B. 071 Wilberforce Island, Bayelsa State, Nigeria \\ ${ }^{2}$ Department of Electrical/Computer Engineering, Rivers State University of Science and Technology, \\ PMB 5080, Nkpolu, Rivers State, Nigeria
}

\section{Doi:10.5901/ajis.2013.v2n13p93}

\begin{abstract}
Nigeria is a country blessed with abundant sources of energy. The choice of energy for electricity generation in an area has always been influenced by political motives that the proper choice of energy type and the economic advantages are not considered. Due to these wrong foundations the stable power supply has been seen in Nigeria as an impossible target. The paper therefore is aimed at considering the available sources of energy in Nigeria and to suggest the best energy mix that will make this dream a reality. For this reason studies were carried out in some parts of the world as regards to: (i) The sources of energy available, (ii) The energy mix, (iii) The generating sources and the available energy. From the study it was seen that Nigeria primary energy resources are in excess of its domestic electric energy requirements that it should not experience electricity supply inadequacies. One of the solutions to adequate and stable power supply is to have a proper energy mix with proper load projection and good management system.
\end{abstract}

Keywords: Energy Mix, Primary Energy Sources, Fossil Fuel, Thermal Energy, Renewable Energy Sources.

\section{Introduction}

In order to optimally develop adequate and stable power supply, proper energy mix is important. This does not serve only as a security strategy but also allow for selection of the appropriate base load for transmission and distribution. Proper energy mix is very important in Nigeria because of the vast energy sources and also the unexpected disruption, pitfall or vandalization.

In 1990, it was reported of low level of water which resulted to load sharing. Presently gas supply if not proper legislated and monitored eventually may result to shortage of power generation.

Nigeria is endowed with several energy resources but proper planning and execution of these resources will result to proper and stable power supply to the nation.

Some of these sources of energy are as follows Coal, natural gas, oil, hydro and other renewable energy sources (Akarakiri, 2002).

\subsection{Coal:}

Coal was first discovered in Nigeria in 1909. Coal mining began in 1916 when Enugu coal fields were opened. Available data showed that coal of sub-bituminous grade occurs in about 22 coal fields spread in over 13 states of Nigeria. The proven coal reserves so far in the country are about 639 million tones while the inferred reserves are about 2.75 million tones. 


\subsection{Oil:}

Oil (crude petroleum) was first found in 1956 at Oloibiri, since then the number of oil reserves in the country has increased (Sambo, 2006). It is projected that proven reserves will reach about 40 billion barrels by year 2010 and potentially 68 billion barrels by year 2030.The crude oil is refined and used in different forms but the reserve will last for over 25 years (Onohaebi, 2007, Onwioduokit, 2000).

\subsection{Gas:}

Considerable reserves of natural gas have been discovered especially in the Niger Delta. This reserve is distributed between associated gas with oil and natural gas. Nigeria currently has 256 trillion sef probable gas reserves, 120 trillion sef proven gas reserves and two billion associated gases produced daily [Sambo 2008, EIA 2007] out of these about 1.75 billion sef gas is flared every day.

\subsection{Renewable Energy:}

Nigeria is endowed with abundant renewable energy resources, the significant ones are solar energy, biomass, wind, small and large hydro power with potential for hydrogen fuel, geothermal and ocean energies (Nwankwo, 2000, ECN, 2004). Except for large scale hydro power which serves as a major source of electricity, the current state of exploitation and utilization of the renewable energy resources in the country is very low, limited largely to pilot and demonstration projects. The energy resources, reserves, production and domestic utilization levels are shown in Table 1.

Table 1: Types of Energy Resources, the Reserves, Production and Domestic Utilization Levels.

\begin{tabular}{|c|c|c|c|c|c|}
\hline \multirow{3}{*}{$\mathbf{S} / \mathbf{N}$} & \multirow[b]{2}{*}{ Resource Type } & \multicolumn{2}{|c|}{ Reserves } & \multirow[b]{2}{*}{ Production } & \multirow{3}{*}{$\begin{array}{c}\text { Domestic } \\
\text { Utilization } \\
\text { (Natural } \\
\text { Units) } \\
\end{array}$} \\
\hline & & \multirow{2}{*}{ (Natural UNits } & $\begin{array}{c}\text { Energy Units } \\
\text { (Btoe*) }\end{array}$ & & \\
\hline & & & & & \\
\hline 1. & Crude Oil & 35 billion barrels & 4.76 & $\begin{array}{l}2.5 \text { million } \\
\text { barrels/day }\end{array}$ & $\begin{array}{c}450,000 \\
\text { barrels/ day }\end{array}$ \\
\hline 2. & Natural Gas & 187 trillion SCF & 4.32 & 6 Billion SCF/day & $\begin{array}{l}3.4 \text { billion } \\
\text { SCF/day }\end{array}$ \\
\hline 3. & Coal and Lignite & 2.176 billion tones & 1.92 & 22.1 tones/day & 22.1 tonnes/day \\
\hline 4. & Tar Sands & $\begin{array}{c}31 \text { billion barrels of } \\
\text { equivalent }\end{array}$ & 4.22 & - & - \\
\hline 5. & Hydropower large & $15,000 \mathrm{MW}$ & $\begin{array}{c}1.11 \text { (over } 38 \\
\text { years) }\end{array}$ & $\begin{array}{l}1,938 \mathrm{MW} \text { (167.4 } \\
\text { million MWH/day) }\end{array}$ & $\begin{array}{l}\text { 167.4 Million } \\
\text { MWH/day }\end{array}$ \\
\hline 6. & Small Hydropower & $3,500 \mathrm{MW}$ & $\begin{array}{c}0.25 \text { (over } 38 \\
\text { years) }\end{array}$ & $\begin{array}{c}30 \mathrm{MW}(2.6 \\
\text { Million MWH/day }\end{array}$ & $\begin{array}{l}2.6 \text { million } \\
\text { MWh/day }\end{array}$ \\
\hline 7. & Solar radiation & $\begin{array}{c}3.5-7.0 \mathrm{KWh} / \mathrm{m}^{2} / \mathrm{day} \\
\text { (485.1 million MWh/dah } \\
\text { using } 0.1 \% \text { Nigeria land } \\
\text { area) }\end{array}$ & $\begin{array}{c}15.0 \text { (38 years and } \\
0.1 \% \text { Nigeria land } \\
\text { area) }\end{array}$ & $\begin{array}{l}\text { Excess of } 240 \\
\text { KWp of solar PV } \\
\text { or } 0.01 \text { million } \\
\text { MWh/day }\end{array}$ & $\begin{array}{c}\text { Excess of } 0.01 \\
\text { million } \\
\text { MWph/day of } \\
\text { solar PV }\end{array}$ \\
\hline 8. & Wind & $(2-4) \mathrm{m} / \mathrm{s}$ at $10 \mathrm{~m}$ height & $\begin{array}{c}8.14(\mathrm{~m} / \mathrm{s} @ 70 \mathrm{~m} \\
\text { height } \Phi 20 \mathrm{~m} \\
\text { windmill, } 0.1 \% \\
\text { land area of } \\
\text { Nigeria over } 38 \\
\text { years) }\end{array}$ & - & - \\
\hline 9. & Fuel wood & $\begin{array}{l}11 \text { million } \\
\text { hectares of }\end{array}$ & - & $\begin{array}{l}0.120 \text { million } \\
\text { tonnes/day }\end{array}$ & $\begin{array}{l}0.120 \text { million } \\
\text { tonnes/day }\end{array}$ \\
\hline
\end{tabular}




\begin{tabular}{|c|c|c|c|c|c|c|c|}
\hline & \multirow{3}{*}{ Biomass } & & $\begin{array}{l}\text { forest and } \\
\text { woodland }\end{array}$ & \multirow{3}{*}{$\begin{array}{c}\text { Excess of } 1.2 \\
\text { tonnes/day }\end{array}$} & & & \\
\hline & & $\begin{array}{l}\text { Animal } \\
\text { waste }\end{array}$ & $\begin{array}{l}211 \text { million } \\
\text { assorted } \\
\text { animals }\end{array}$ & & - & $\begin{array}{c}0.781 \text { million } \\
\text { tonnes of } \\
\text { waste/day }\end{array}$ & Not available \\
\hline & & $\begin{array}{c}\text { Energy } \\
\text { drops and } \\
\text { Agric } \\
\text { Residue }\end{array}$ & $\begin{array}{c}72 \text { hectares of } \\
\text { Agric. Land }\end{array}$ & & - & $\begin{array}{c}0.256 \text { million } \\
\text { tonnes of assorted } \\
\text { crops/day }\end{array}$ & Not available \\
\hline 10. & Nuclea & $\mathrm{r}$ Element & Not yet $\mathrm{q}$ & ualified & - & - & - \\
\hline
\end{tabular}

Billion Tonnes of oil equivalent

\subsection{Non-Commercial Energy Sector}

The non-commercial energy sector is dominated by primary biomass resources in the country which includes wood, charcoal, gasses and shrubs residues and wastes (agricultural, forestry, municipal and industrial) and aquatic biomass. The total biomass potential in Nigeria, consisting of animal and agricultural wastes and wood residues was estimated to be about 1.2 PJ in 1990 (Fagbenle et al, 2008, Obioh, 2004).

\section{Energy Supply Mix}

For over twenty years prior to 1990, the power sector did not witness substantial investment in infrastructural development. During that period, new plants were not constructed and the existing ones were not properly maintained, bringing the power sector to a deplorable state.

In 2001, generation went down from the installed capacity of about $5600 \mathrm{MW}$ to an average of about $1750 \mathrm{MW}$, as compared to a load demand of $6000 \mathrm{MW}$. Also, only nineteen out of the seventy-nine installed generating units were in operation.

Presently, the government is trying to build and upgrade existing ones to make the power sector have some burst. This has yielded some effort through state governments, federal and some independent power producers (IPP). As at 2005 the grid electricity generation was given at 31.30\% for large hydro plants and 68.30 was accounted for by natural gas. The energy mix proposed up to 2030 is given in table 2.

Table 2: Future installed Electricity Generation Capacity by Fuel. (\%)

\begin{tabular}{|c|c|c|c|c|c|}
\hline Fuel type & 2010 & 2015 & 2020 & 2025 & 2030 \\
\hline Coal & 0.0 & 9.9 & 13.8 & 15.3 & 15.6 \\
\hline Gas & 78.6 & 48.5 & 53.5 & 53.30 & 59 \\
\hline Hydro & 21.3 & 18.9 & 13.6 & 10.7 & 8.6 \\
\hline Nuclear & 0.0 & 9.4 & 5.3 & 8.3 & 6.7 \\
\hline Solar & 0.1 & 13.1 & 11.0 & 10.4 & 8.3 \\
\hline Wind & 0.0 & 0.1 & 2.9 & 2.3 & 1.8 \\
\hline
\end{tabular}

\section{Energy Availability and Management}

The selection of electricity production modes and their economic viability varies in accordance with demand and region. All forms of energy have their 'pros and cons', and their selection is based upon the local power requirement and the fluctuation in demand. Thermal energy is economical in areas of high industrial density as high demand can not be met by renewable sources.

Thermal power plants can also withstand variation in load and consumption by adding more units or temporarily decreasing the production of some units. 
Hydro power plants are located in areas where the potential energy from flowing water can be harnessed for moving turbines and the generation of power. It is not an economically (IEP, 2003) viable source of production were the load varies too much during the annual production cycles and the ability to stop the flow of water is limited.

Renewable sources (solar power, wind power, tidal power etc.) are currently expensive to produce, though with advancement in technology their cost of production is coming down.

Nuclear power plant can produce a huge among of power from a single unit. However, recent disasters in Japan have raise concerned over the safety of Nuclear Power.

A well planned power generation will depend on proper consideration of available energy sources and their need and their effect and influence on the environments (EAN, 2008).

The energy sources and generation for electricity in the globe is given in table 3.

Table 3: Energy Sources and Generation for Electricity in the Globe

\begin{tabular}{|c|c|c|c|c|c|c|c|c|c|c|c|c|c|c|c|c|c|c|}
\hline \multicolumn{19}{|c|}{ Composition of Electricity by Resource (TWh per year 2008) } \\
\hline \multirow[b]{2}{*}{ Country } & \multicolumn{5}{|c|}{ Fossil Fuel } & \multirow[b]{2}{*}{ Nuclear } & \multirow[b]{2}{*}{ rank } & \multicolumn{8}{|c|}{ Renewable } & \multirow[b]{2}{*}{$\begin{array}{c}\text { Bio } \\
\text { other* }\end{array}$} & \multirow[b]{2}{*}{ total } & \multirow[b]{2}{*}{ rank } \\
\hline & Coal & Oil & Gas & \begin{tabular}{|c|} 
sub \\
total
\end{tabular} & rank & & & H & \begin{tabular}{|c|} 
Geo \\
Thermal
\end{tabular} & $\begin{array}{l}\text { Solar } \\
\text { PV* }\end{array}$ & \begin{tabular}{|c|} 
Solar \\
Thermal
\end{tabular} & Wind & Tide & \begin{tabular}{|c|} 
sub \\
total
\end{tabular} & ran & & & \\
\hline World total & 8,263 & 1,111 & 4,301 & 13,675 & - & 2,731 & - & 3,288 & 65 & 12 & 0.9 & 219 & 0.5 & 3,584 & - & 271 & 20,261 & - \\
\hline \begin{tabular}{|l|} 
Proportion \\
\end{tabular} & $41 \%$ & $5.5 \%$ & $21 \%$ & $67 \%$ & - & $13 \%$ & - & $16 \%$ & $0.3 \%$ & $0.06 \%$ & $0.004 \%$ & $1.1 \%$ & $0.003 \%$ & $18 \%$ & - & $1.3 \%$ & $100 \%$ & - \\
\hline China & 2,733 & 23 & 31 & 2,788 & 2 & 68 & 8 & 585 & & 0.2 & 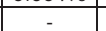 & 13 & 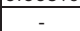 & \begin{tabular}{|l|}
598 \\
\end{tabular} & 1 & 2.4 & 3,457 & 2 \\
\hline India & 569 & 34 & 82 & 685 & 5 & 15 & -6 & 114 & - & 0.02 & & 14 & - & 128.02 & 6 & 2.0 & 830 & 5 \\
\hline USA & 2,133 & 58 & 911 & 3,101 & 1 & 838 & 1 & 282 & 17 & 1.6 & .88 & 56 & & 357 & 4 & 73 & 4,369 & 1 \\
\hline Indor & 61 & 43 & 25 & 130 & 19 & - & - & 12 & 8.3 & 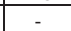 & & 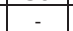 & - & 20 & 17 & & 149 & 20 \\
\hline Brazil & 13 & 18 & 29 & 59 & 23 & 14 & 13 & 370 & - & - & - & 0.6 & - & 370 & 3 & 20 & 463 & 9 \\
\hline Nigeria & & 3.1 & 12 & 15 & 28 & +4 & & 5.7 & - & - & - & - & - & 5.7 & 25 & & 21 & 28 \\
\hline Russ & 197 & 16 & 495 & 708 & 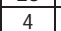 & 163 & 4 & 167 & 0.5 & - & - & 0.01 & 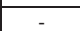 & 167 & 5 & 2.5 & 1,040 & 4 \\
\hline Japa & 288 & 139 & 283 & 711 & 3 & 58 & 3 & 83 & 2. & 2.3 & 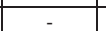 & 2.6 & - & 91 & 7 & 22 & 1,082 & 3 \\
\hline Mexicc & 21 & 49 & 131 & 202 & 13 & 9.8 & 14 & 39 & 7.1 & 0.01 & - & 0.3 & - & 47 & 12 & 0.8 & 259 & 14 \\
\hline Egypt & - & 26 & 90 & 115 & 20 & - & - & 15 & - & - & - & 0.9 & - & 16 & 20 & - & 131 & 22 \\
\hline Germa & 291 & 9.2 & 88 & 388 & 6 & 148 & 5 & 27 & 0.02 & 4.4 & 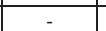 & 41 & - & 72 & 9 & 29 & 637 & 7 \\
\hline Tur & & 7.5 & 99 & 164 & 16 & & 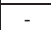 & 33 & 0.16 & & - & 0.85 & - & 34 & 13 & 0.22 & 198 & 19 \\
\hline Franc & & 5.8 & 22 & 55 & 24 & 30 & 2 & 68 & $=$ & 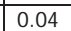 & - & 5.7 & 0.51 & 75 & 8 & 5.9 & 575 & 8 \\
\hline UK & 127 & 6.1 & 177 & 310 & 7 & 52 & 10 & 9.3 & - & 0.02 & - & 7.1 & - & 16 & 18 & 11 & 389 & 11 \\
\hline Italy & 49 & 31 & 173 & 253 & 9 & 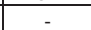 & - & 47 & 5.5 & 0.2 & - & 4.9 & - & 58 & 11 & 8.6 & 319 & 12 \\
\hline South K & 192 & 15 & 81 & 288 & 8 & 151 & 5 & 5.6 & - & 0.3 & - & 0.4 & - & 6.3 & 24 & 0.7 & 446 & 10 \\
\hline Spain & 50 & 18 & 122 & 190 & 14 & 59 & y & 26 & - & 2.6 & 0.02 & 32 & - & 61 & 10 & 4.3 & 314 & 13 \\
\hline Cal & 112 & 9.8 & 41 & 162 & 17 & 94 & 7 & 383 & - & 0.03 & 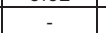 & 3.8 & 0.03 & 386 & 2 & 8.5 & 651 & 6 \\
\hline \begin{tabular}{|l|} 
Australia \\
\end{tabular} & 198 & 2.8 & 39 & 239 & 10 & 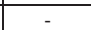 & - & 12 & - & 0.2 & 0.004 & 3.9 & 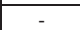 & 16 & 19 & 2.2 & 257 & 15 \\
\hline
\end{tabular}

The load summary is given in table 4

Table 4: Sources of Electricity (World Total in 2008)

\begin{tabular}{|l|c|c|c|c|c|c|c|}
\hline \multicolumn{1}{|c|}{ Sources } & Coal & Oil & Natural Gas & Nuclear & Hydro & Others & total \\
\hline Ave. Electric Power (TWH/year) & 8,263 & 1,111 & 4,301 & 2,731 & 3,288 & 568 & 20,261 \\
\hline Ave. Electric Power (GW) & $9,42.6$ & 126.7 & 490.7 & 311.6 & 375.1 & 64.8 & 2311.4 \\
\hline Proportion \% & $41 \%$ & $5 \%$ & 21 & 13 & 16 & 3 & 100 \\
\hline
\end{tabular}

The global source of electricity distributions were fossil fuels 67 percent, renewable energy 16 percent (mainly hydro electric, wind, solar and biomass), nuclear power is 13 percent and other sources 3 percent. The majority of fossil fuel usage for generation of electricity was coal and gas. Oil was 5.5 percent, as it is the most expensive common commodity used for electricity generation (ClA, 2009).

The global distribution of fossil fuel is given in fig. 1 . 


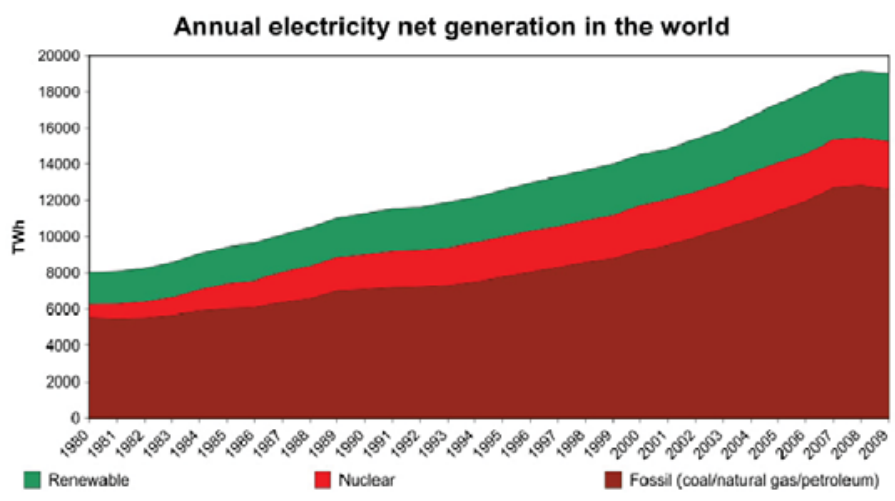

Fig. 1: Annual Electricity Net Generation in the World

Ninety-two percent of renewable was hydro electric, followed by wind 6 percent, geothermal 1.8 percent, solar voltaic 0.06 percent and solar thermal 0.04 percent. The distribution is shown in fig. 2

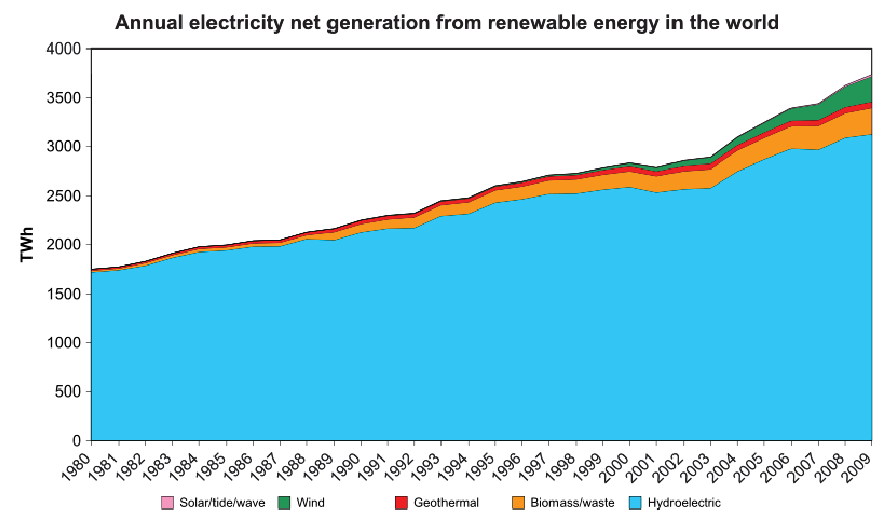

Fig. 2: Annual Electricity Generation from Renewable Energy in the World

Energy mix for electricity supply depends largely on the sources of available energy and the available quantity.

In the United States, the majority of this electric energy is derived from fossil fuels. In 2012 data showed that 25 percent of the nation's energy came from petroleum, 22 percent from coal, 22 percent from natural gas.

Nuclear power supplied 8.4 percent and renewable is 8 percent which was mainly from hydro electric dams.

In India which is the fifth electric energy producers has coal fired plant and that account for 57 percent of India's installed electricity, as compared to Australia is 76 percent, China is 75 percent, South Africa is 92 percent.

Renewable hydro power account for 19 percent, renewable energy 12 percent and natural gas is 9 percent.

The primary energy supply for South Africa energy sector is dominated by coal. It is plentiful and inexpensive. It supply is placed at 4.782 PJ for the year 2000. The energy distribution is shown in fig. 3. 


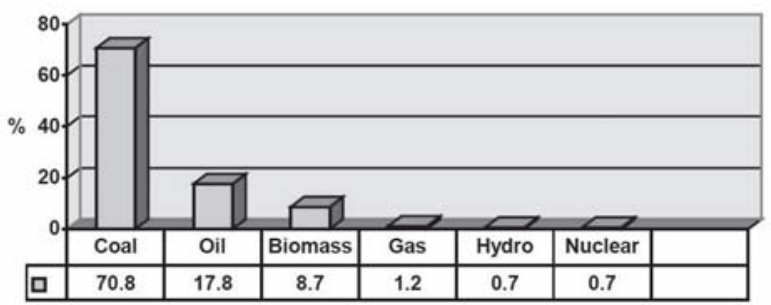

Fig. 3: Energy Distribution of South Africa

Most of South Africa liquid fuel requirements are imported in the form of crude oil. Approximately $30 \%$ of South Africa's liquid fuel requirements are sourced from coal via Sasol.

According to International Energy Agency (IEA) in 2008, the total energy consumption in Nigeria was 4.4 Quadrillion (BTU) (111,000 Kilotons) of oil equivalent. Of this, combustible renewable and waste account for 81.3 percent of total energy consumption. This high percent share represents the use of biomass to meet off grid heating and cooking needs, mainly in rural areas (EAN, 2008). The division of energy usuage is shown in fig. 4

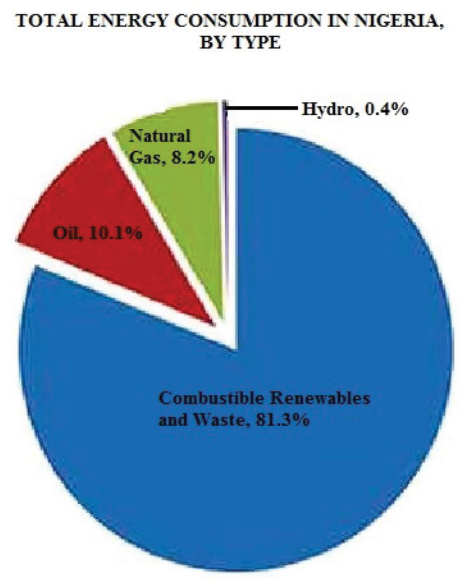

Fig. 4: Total Energy Consumption in Nigeria, by type.

IEA data in 2009 indicates that electrification rates for Nigeria were 50 percent for the country as a whole, approximately 76 million people do not have access to electricity in Nigeria ( $\mathrm{ClA}, 2009)$. The other population solely depends on combustible renewable energy.

\section{Discussion}

Considering the global electricity market trend, Nigeria is far from realizing the expected target. This was not as a result of the scarce commodity but the lack of proper management to harness the available resources. Nigeria is considered as one of the energy rich country in the world. Nigeria is rated among the top oil producer in Africa, second in natural gas reserve (with an estimate of 176 trillion cubic feet) and an estimated 2 billion metric tones of coal.

From table 3, only natural gas (12) and fuel (3.1) account the fossil fuel used as against the daily demand. The only renewable is the large hydro that accounts for the rest of electricity generation.

Hydro electric generation potential is very high. Added to the four existing plants, 8 were 
planned survey and not executed (ECN, 2004). The table 5 shows the proposed planned hydro electric generations.

Table 5: Potential Hydro-power Development in Nigeria

\begin{tabular}{|l|l|c|}
\hline \multicolumn{1}{|c|}{ Site } & \multicolumn{1}{|c|}{ River } & Capacity MW \\
\hline Lokoja-North & Niger & 950 \\
Onisha South & Niger & 750 \\
Makudi North & Benue & 800 \\
Zungeru I-North & Kaduna & 500 \\
Zungeru II-North & Kaduna & 450 \\
Yola-North & Benue & 350 \\
Kastina Ala-North & Kastina-Ala & 260 \\
Beli-North & Taraba & 240 \\
Garindala North & Taraba & 135 \\
Gembu-North & Donga & 130 \\
Ikom-North & Cross & 400 \\
Afikpo-South & Cross & 180 \\
Afan-South & Cross & 180 \\
\hline
\end{tabular}

Source: Electricity supply in Nigeria (Nwankwo, 2000)

The Nigerian Government has had several plans to address the need for power, including a recent announcement to create 40 gigawats (GW) of capacity by 2020 compared to 2008 installed capacity of $6 \mathrm{GW}$. This power sector reform included a roadmap which targeted at gradual increase of power supply, transmission and the distribution level. The table (table 6) shows the target set up to 2013.

Table 6: Target Increase in Generation, Transmission and Distribution Capacity.

\begin{tabular}{|c|c|c|c|c|}
\hline \multirow{2}{*}{ Period } & \multirow{2}{*}{ Available Gen. generation capacity } & \multicolumn{2}{|c|}{ Transmission capacity GW } & \multirow{2}{*}{ Distribution capacity (GW) } \\
\cline { 3 - 4 } & & $330 \mathrm{KV}$ & $132 \mathrm{KV}$ & 5758 \\
July 2010 & 4.612 & 5155 & 6677 & 6334 \\
Dec. 2010 & 5.379 & 5155 & 7328 & 6900 \\
April 2011 & 7.033 & 5995 & 7328 & 7485 \\
Dec. 2011 & 9769 & 6555 & 7488 & 8061 \\
Dec. 2012 & 11879 & 7866 & 8986 & 9059 \\
Dec. 2013 & 14218 & 8653 & 9885 & \\
\hline
\end{tabular}

Source: Roadmap for power sector reform-Presidency, August 2010.

These are noble plans on the side of the government but due to absence of infrastructural development and other factors, Nigeria is far from achieving it.

Apart from the large hydro electric generation, the potentials for the mini and micro hydro potentials are enormous. The wind energy would strive very well in the Northern part of Nigeria and at the coast of the Niger Delta. Due to the location of Nigeria (the nearness to the equator) solar power could be available for 12 to 13 hours in the day with solar intensity of 5 to $7 \mathrm{kwh} / \mathrm{m} 2$ per day.

\section{Conclusion}

With the abundance of energy resources, Nigeria need not import energy to achieve a sustainable generating capacity suffices the targeted economic growth and also has excess generation to sell to 
neighbouring countries.

In the face of global electricity market trend which focuses on building a cleaner, more diverse and more sustainable electricity mix, Nigeria has the resources to meet this target. However, the country is lacking in policies and the will power to harness resources and develop and/or improve the electricity infrastructure.

Nigeria has been able to trace the collapse of the industrial sector, small and medium scale businesses and economic standstill of the nation to the inadequate and erratic state of the country's electricity market.

Several commitments have been made by different governments of Nigeria financially and to some point human resources but such huge financial commitments are sabotaged by

i. Selfish political Motive - Putting the wrong persons in positions and sitting the infrastructures at the wrong location incurring heavy losses. No clear description of roles and responsibilities of appointed committees and offices.

ii. Greed and corruption - siphoning the money committed through back door, heavy kick backs, and purchasing old equipment.

iii. Vandalism and theft - transmission lines and transformers are vandalized at will. Illegal connection and theft due to improper monitoring and sometimes abated by the electricity employee.

Others are

* Insufficient transmission and distribution facilities

* Ineffective regulation

* In-appropriate industries and market structure

Electricity is fundamental and inevitable to our daily living as well as the sustainability of our industrial growth.

It poses threat to a country's national economic sustainability development and appreciable growth is conspicuous in various nations of the world. We therefore commend the present government in taken the country out of this deplorable state but it is necessary to mention that proper energy mix is a sure way of reaching the proper landmark.

The environmental effect on water level (hydroelectricity) has been reported. The vandalism of pipes and the activities of militants also have not been pleasant in the past years. The only way to enhance energy security (total blackout or load sharing) is to broaden the nation's energy supply mix. From the available energy resources of Nigeria it is proper to recommend that no one source of energy be more than forty $(40 \%)$ percent.

\section{References}

Akarakiri, J.B. (2002). Rural Energy in Nigeria. The Electricity Alternative: Domestic use of Energy Conference, pp. 1 - 7.

$\mathrm{ClA}$ World Factbook (2009). Central Intelligence Agency (ClA), United States of America.

E.C.N. (2004). National Energy Policy, Federal Republic of Nigeria, Published by the Energy Commission of Nigeria (ECN).

EIA (2007). Country Analysis Brief - Nigeria, Energy Information Administration (ElA), Department of Energy, U.S. Government.

Energy Agency (2008). Energy (EAN) balance for the world.

Fagbenle, R.Q, Adeleja A.O. and Bellow, A.K. (2008). Modeling of Wired Energy Potential in Nigeria. Final Report of the Power Sector Reform committee, Abuja.

IEP (2003). Integrated Energy Plan for the Republic of South Africa, Department of Minerals and Energy. Nwankwo, O.I. (2000). Electricity Supply in Nigeria, $4^{\text {th }}$ International Conference on Power Systems Operation and Planning, Accra, Ghana: 147 - 150.

Obioha, I.B. (2004). Trends in Greenhouse Gas Emission in Nigeria, 1988 - 2000, A Project Report submitted to the Nigerian Environmental Study/Action Team (NEST), I badan.

Onohaebi, O.S. (2009). Power Outages in the Nigerian Transmission Grid, Research Journal of Applied 
Sciences, 4(1): 1 - 9.

Onwioduokit A. (2000). Privatization of Power Utility in Nigeria; Issues and options, in Proceeding of the 4th International Conference on Power Systems Operation and Planning, Accra, Ghana, pp. 36 40.

Sambo, A.S. (2006). Renewable Energy Electricity in Nigeria the way forward, in Proceeding of the Renewable Electricity Policy Conference, Abuja, Nigeria, pp. 1 - 42.

Sambo, A.S. (2008). The Role of Energy in Achieving Millennium Development Goals (MDGs) National Engineering Tech. Conference (NETEC), 1 - 42. 
